\title{
Composition, properties, and nutritive value of dietary fibre of legume seeds. A review
}

\author{
Jolanta Gdala \\ The Kielanowski Institute of Animal Physiology and Nutrition, \\ Polish Academy of Sciences \\ 05-110 Jablonna, Poland
}

(Received 3 February 1998; accepted 25 March 1998)

\begin{abstract}
Non-starch polysaccharides (NSP) and lignin are the principal components of dietary fibre. Legume seeds such as faba beans, peas, and lupins contain considerable amounts of non-starch polysaccharides. The average NSP content is $177 \mathrm{~g}$ in faba beans, $185 \mathrm{~g}$ in peas, and from 320 to $400 \mathrm{~g} / \mathrm{kg}$ DM in different lupin species. Seeds of Lupinus angustifolius contain more NSP than seeds of Lupinus luteus and Lupinus albus. Differences among lupin species in the NSP level result from differences in the content of NSP sugar residues, particularly rhamnose, xylose, galactose, and uronic acids. Glucose and galactose constitute the main part of NSP sugar residues in lupin seeds. NSP of pea seeds and faba beans are mainly composed of glucose, arabinose and uronic acids. Dietary fibre of legume seeds may also include other components such as $\alpha$-galactosides, resistant starch, polyphenols, and protein bound to cell walls.

Different proportions of carbohydrates either hydrolysed by endogenous enzymes or fermented by gut microflora and of fat result in a differnt energy value of the legume seeds for animals. Since bacterial fermentation of NSP is more intense in the hind-gut of pigs, legume seeds have a higher energy value for these animals than for poultry.

A high NSP content in animal diets negatively affects digestibility and nutrient absorption, while it may have beneficial dietary effects on humans. Different treatments, i.e. dehulling, microbial enzyme supplementation, are used to improve the nutritional value of legume seeds for monogastric animals.
\end{abstract}

KEY WORDS: legume seeds, NSP, chemical composition, nutritional effects

\section{INTRODUCTION}

Non-starch polysaccharides (NSP) and lignin are the principal components of dietary fibre (Southgate, 1982). The NSP include mainly cellulose, hemicelluloses 
and pectic substances (Arora, 1983), while lignin is a high molecular weight polymeric material formed by enzymatic dehydrogenation and polymerisation of hydroxycinnamyl alcohols (Annison, 1993). Lignin forms complexes with the nonstarch polysaccharides which protect cells from biochemical degradation and physical damage. Cell wall polysaccharides can affect many processes along the entire gastro-intestinal tract in man or animals (Low, 1985; Graham et al., 1990). The physiological effects of the NSP depend, however, on their composition and physico-chemical properties (i.e. solubility, particle size, fermentability). In general, viscous polysaccharides (gums, pectin substances) reduce the rate of nutrient absorption in the small intestine, whereas insoluble cell wall polysaccharides have only little effect on this process.

In most European countries legume seeds such as peas, faba beans, and lupins are an important source of protein and energy for non-ruminant animals. They contain a high amount of protein, starch and/or oil (Daveby and Åman, 1993; Petterson and Mackintosh, 1994), but also have a considerable amount of nonstarch polysaccharides. The average content of NSP is $177 \mathrm{~g}$ in faba beans, $185 \mathrm{~g}$ in pea seeds and from 320 to $400 \mathrm{~g} / \mathrm{kg} \mathrm{DM}$ in different lupin species (Gdala and Buraczewska, 1996; 1997a). So far, few studies refer to their chemical composition (Cerning et al., 1975; Cerning-Beroard and Filiatre, 1976; Brillouet and Riochet, 1983; Carr et al., 1985; Evans et al., 1993).

This paper will review the chemical composition of the major components of non-starch polysaccharides of whole seeds of lupins, peas, and faba beans and of hulls and cotyledons. The nutritional effects of non-starch polysaccharides of legume seeds in non-ruminant animals and humans are discussed.

\section{CONTENT AND CHEMICAL COMPOSITION OF DIETARY FIBRE COMPO- NENTS OF LEGUME SEEDS}

\section{NON-STARCH POLYSACCHARIDES AND LIGNIN}

\section{Lupinus luteus, Lupinus albus, Lupinus angustifolius}

The NSP content varies from 270 to $350 \mathrm{~g} / \mathrm{kg}$ DM in Lupinus luteus varieties, from 350 to $420 \mathrm{~g}$ in Lupinus albus and up to an average of $400 \mathrm{~g}$ in varieties of Lupinus angustifolius (Gdala and Buraczewska, 1996). NSP are composed in 32\% of cellulose and $68 \%$ of non-cellulosic polysaccharides (Bach Knudsen, 1997). The latter comprise the soluble (49\%) and insoluble (51\%) fraction.

Seeds of Lupinus angustifolius have more NSP than seeds of Lupinus albus and Lupinus luteus. This probably relates to considerable differences among species in the content of rhamnose, xylose, uronic acids and galactose residues. In general, 
glucose and galactose with an average contribution of up to 34 and $30 \%$, respectively, are the main sugar components in lupin seed non-starch polysaccharides (Gdala and Buraczewska, 1996).

Depending on the lupin species, hulls represent from 122 to $310 \mathrm{~g} / \mathrm{kg}$ of whole seed weight. Sweet lupin hulls contain from 760 to $790 \mathrm{~g}$ of NSP and from 17 to $21 \mathrm{~g}$ of lignin per kg DM (Brilloulet and Riochet, 1983). Small amounts of protein and ash are also detected. Cellulose is the major constituent $(51 \%)$ of hull structural polysaccharides. Other sugar components such as xylose, uronic acids, arabinose, and galactose indicate that lupin hulls contain, on dry matter basis, appreciable amounts of hemicelluloses $(127 \mathrm{~g} / \mathrm{kg}$ ) and pectic substances $(277 \mathrm{~g} / \mathrm{kg}$ ) (Bailey et al., 1974). Mohamed and Rayas-Duarte (1995) reported that some hemicellulose and pectic substances remained associated with the cellulose fraction of L.albus hulls.

According to Evans et al. (1993) approximately $50 \mathrm{~g} / \mathrm{kg}$ of hull NSP is soluble in water. The chemical composition of this fraction, however, is different than that of the total NSP. The relatively high content of mannose, galactose, xylose and uronic acids might indicate the presence of pectins, xyloglucan and other hemicellulose type polymers.

The cotyledon cell walls of $L$. angustifolius cultivars contain from 290 to 310 $\mathrm{g} / \mathrm{kg}$ DM of NSP (Evans et al., 1993) with galactose, arabinose and uronic acids as the main sugar residues. Glucose, xylose and rhamnose are found in smaller amounts. This qualitative sugar composition is typical of all legume cotyledon walls, which are composed mainly of pectic substances, i.e. arabinans, arabinogalactans, rhamnogalactouronans, and have a low cellulose content (Brillouet and Riochet, 1983; Evans et al., 1993).

Eighty-eight percent of the cotyledon polysaccharides from white lupin are the water-soluble fraction, containing mostly galactose and mannose. Galactose and arabinose dominate in the water-insoluble fraction (Mohamed and Rayas-Duarte, 1995).

Pisum sativum subsp. sativum, Pisum sativum subsp. arvense

Seed maturation has a significant effect on the composition of pea non-starch polysaccharides since the concentration of cellulose increases rapidly in the early stage of seed development (Weightmantet al., 1993). The level of non-starch polysaccharides in whole mature pea seeds ranges from 160 to $201 \mathrm{~g} / \mathrm{kg} \mathrm{DM}$. The main sugar residues are glucose, arabinose and uronic acids. Rhamnose, mannose and fucose are minor components. Proportions of particular NSP residues in white (Pisum sativum subsp.sativum) - and colour-floured (Pisum sativum subsp. arvense) peas are similar (Gdala and Buraczewska, 1997a). The pea NSP are composed in $30 \%$ of cellulose and in $70 \%$ of non-cellulosic polysaccharides (Bach Knudsen, 1997). 
Depending on the pea variety, hulls may constitute from 70 to $140 \mathrm{~g} / \mathrm{kg}$ of seeds (Daveby and Åman, 1993). Hulls are characterised by a high level of carbohydrates $(942 \mathrm{~g} / \mathrm{kg}$ ) and a low content of lignin $(6 \mathrm{~g} / \mathrm{kg})$ (Weightman et al., 1994). The contents of NSP and lignin differ, however, between light and dark hulls. The former have higher content of NSP residues ( $870 \mathrm{vs} 844 \mathrm{~g} / \mathrm{kg} \mathrm{DM})$, while the latter contain much more Klason lignin (29 vs $18 \mathrm{~g} / \mathrm{kg} \mathrm{DM}$ ) (Daveby and Åman, 1993). Major NSP residues of pea hulls are glucose, uronic acids and xylose, which suggests a high cellulose content, but also the occurrence of pectic substances and hemicelluloses (Ralet and Thibault, 1992). According to Weightman et al. (1994) hemicelluloses present in pea hulls appear to be essentially pure acidic xylan.

The dietary fibre content in dehulled pea seeds is from 68 to $92 \mathrm{~g} / \mathrm{kg} \mathrm{DM}$ (Daveby and Åman, 1993). Cell walls of dehulled pea seeds are mainly composed of pectic polysaccharides containing arabinose, galactose, uronic acids and rhamnose. In pectin about $86 \%$ of the neutral sugars, mostly arabinose and galactose, is attached covalently to polyuronide chains probably as constituents of rhamnogalacturonans (Tallbot and Ray, 1992). The hemicellulose fraction with arabinogalactans (at least $60 \%$ of their total amounts) and xyloglucans as well as cellulose are other important cell wall polysaccharides in dehulled peas (Daveby and Åman, 1993).

Similarly to other legume seeds, pectin, galactan and arabinan are the main pectic polysaccharides present in pea seeds (Arora, 1983)

\section{Vicia faba minor}

Whole faba beans have from 173 to $181 \mathrm{~g} / \mathrm{kg}$ DM of NSP that are composed in $55 \%$ of glucose (Gdala and Buraczewska, 1997a). The high level of the glucose residue proves that cellulose is a major component ( $43 \%$ ) of the faba bean nonstarch polysaccharides (Bach Knudsen, 1997). Considering average proportions of other NSP constituents, uronic acids, arabinose, xylose and galactose have intermediate values, while mannose, rhamnose and fucose are found to be minor sugar residues.

Hulls constitute about $130 \mathrm{~g} / \mathrm{kg}$ of whole faba beans. They are mainly composed of dietary fibre $(910 \mathrm{~g} / \mathrm{kg}$ D*1) that contains $85 \%$ non-starch polysaccharides and 15\% Klason lignin (Daveby and Åman, 1993). Glucose, uronic acids and xylose are the main monosugar components of NSP.

In water-soluble fraction of cotyledon NSP arabinose is the major sugar constituent and it is followed by galactose, galactouronic acid, glucose and minor amounts of rhamnose, mannose and xylose (Brillouet and Carré, 1983). The mannose residue indicates the presence of side chains of endospermic galactomannas composed of varying proportions of $\alpha$-galactopyranose units that are attached to the main chains of $\beta$-D-mannopyranose residues (Aspinall, 1970). Pectic substances 
represent about $55 \%$ of cell walls as determined by colorimetric analysis of acidic and neutral sugars. Arabinose is their major monosaccharide constituent, while xylose, galactose, glucose, and rhamnose have a smaller contribution (Brillouet and Carré, 1983).

Water-insoluble polysaccharides are mainly composed of cellulose, the amount of which corresponds to $8 \mathrm{~g} / \mathrm{kg}$ of cotyledon dry matter. Faba bean flour contains also $4 \mathrm{~g} / \mathrm{kg}$ of water insoluble non-starchy and non-cellulosic glucose polymers (Brillouet and Carré, 1983).

In general, seeds of $L$. angustifolius contain more NSP than seeds of L. luteus and $L$. albus. Glucose and galactose constitute the main part of NSP sugar residues. Considerable differences among lupin species are found in the contents of rhamnose, xylose, galactose and uronic acids (Gdala and Buraczewska, 1996). In comparison with seeds of lupins, pea seeds and faba beans contain less non-starch polysaccharides which are mainly composed of glucose, arabinose and uronic acids (Gdala and Buraczewska, 1997a). There are no significant differences among cultivars within either pea or faba bean species in terms of NSP content and their chemical composition. More cellulose is present in faba bean NSP than in those of pea seeds (Bach Knudsen, 1997).

\section{OTHER COMPONENTS OF LEGUME SEED DIETARY FIBRE}

Besides non-starch polysaccharides, dietary fibre (DF) may include oligosaccharides, resistant starch, polyphenols, proteins bound to cell walls, and also (not important in legume seeds) cutin, waxes, suberin, and inorganic constituents (Englyst et al., 1987; Annison, 1993).

The most common oligosaccharides occurring in plants are sucrose and lactose. These oligosaccharides are not included into DF as they are hydrolysed in the small intestine of human and pigs by sucrase and lactase, respectively. Higher oligosaccharides i.e. $\alpha$-galactosides (raffinose, stachyose, and verbascose) occur in appreciable amounts in legume seeds.

The content of $\alpha$-galactosides differs among lupin species from about $60 \mathrm{~g}$ in L. angustifolius to $105 \mathrm{~g} / \mathrm{kg} \mathrm{DM}$ in L. luteus. Faba beans contain on average about $28 \mathrm{~g} / \mathrm{kg}$, and peas $58 \mathrm{~g} / \mathrm{kg}$ DM of $\alpha$-galactosides. Stachyose is a major $\alpha$-galactoside of lupin seeds, verbascose of faba beans, whereas both stachyose and verbascose dominate in pea seeds (Gdala and Buraczewska, 1996, 1997). Alpha-galactosides are not broken down by endogenous enzymes of non ruminants, but they are microbially fermented (Krause et al., 1994). The bacterial fermentation results in formation of short chain fatty acids, carbon dioxide, and hydrogen. The presence of gases in the gut is the main reason of flatulence, nausea, and of animal discom- 
fort (Macrae and Zand-Moghaddam, 1978). Moreover, $\alpha$-galactosides increases the amount of water and electrolytes in the large intestine (Cummings et al., 1986). This is due to high osmotic pressure of their water solution.

Resistant starch is proposed to be defined as "the sum of starch and starchdegradation products that reach the human large intestine" (Englyst et al., 1996). Raw starch that is trapped within whole plant cells or within the food matrix may resist digestion by $\alpha$-amylase in the small intestine. The other reasons for poor starch digestibility are the structure of the starch granules and starch retrogradation through food processing (Cummings et al., 1996). When resistant starch reaches the colon, it becomes available for fermentation by microflora. In this respect it is similar to non-starch polysaccharides. Peas and faba beans contained about $14 \%$ enzyme-resistant starch as measured under in vitro conditions (Gdala and Buraczewska, 1997b), but in some pea varieties its level is as high as $20 \%$ (Colonna and Mercier, 1979). It is difficult to measure the amount of starch that escapes hydrolysis and absorption in the small intestine. In man, depending on the type of food and its processing, it may exceed by up to eight times the amount of NSP passing into the colon (Cummings et al., 1986). The average ileal starch digestibility in pigs was only $86 \%$ for peas and $84 \%$ for faba beans (Gdala and Buraczewska, 1997b).

Tannins are high-molecular weight polyphenols that form stable complexes with proteins, cellulose, hemicellulose, and pectin (Mangan, 1988). Legume seeds, except soya bean, contain significant amounts of tannins, most of which occur in the seed coat. The average content of total phenols in whole white- and colour flowered pea, faba bean, and lupin expressed as tannic acid equivalent is about 2.0 and $7.5,8.3$, and $0.2 \mathrm{mg} / \mathrm{g}$, respectively (Narasinga Rao and Prabhavathi, 1982; Buraczewska et al., 1992; Gdala et al., 1992). In comparison, their content is higher in hulls of pea and faba bean (11.1 and $21.7 \mathrm{~g} / \mathrm{kg}$ ) and lower $(0.04 \mathrm{~g} / \mathrm{kg}$ ) in that of lupin seeds (Saini, 1993). Daveby and Åman (1993) reported that the tannin content may change the level of dietary fibre in hulls of different pea varieties. The higher level of dietary fibre in hulls of dark-flowered peas than in light-flowered varieties resulted mainly from a higher condensed tannin content of Klason lignin in the former.

Proteins are bound to cell wall polysaccharides in appreciable amounts (Ménez et al., 1993; Saulnier et al., 1995). The nature of linkages between protein and polysaccharides remains unclear, so far. Among proteins present in dietary fibre, extensins are major glycoproteins of dicots structural cell walls (Bjergegaard et al., 1997). In total, cell walls of roots, stems, and seed coats contain up to $7 \%$ of extensins (O'Neill and Selvendran, 1980), but only trace amounts of these glycoproteins are present in cell wall of maize belonging to graminaceous monocots (Kieliszewski and Lamport, 1987). Other proteins present in cell walls are arabinogalactan-proteins, arabinoxylan-proteins, and proline rich 
proteins (Rybka1993; Bjergegaard et al., 1997). These, however, are found in small amounts both in mono- and dicots.

\section{ENERGY UTILISATION OF LOW DIGESTIBLE CARBOHYDRATES}

The nutritive value of feedstuffs depends on the digestibility and utilisation of carbohydrates as they are the largest contributors to the energy of the animal. From the nutritional point of view plant carbohydrates can be divided into two groups: carbohydrates digested by mammalian digestive enzymes in the small intestine i.e. sucrose, starch, and those not hydrolysed by enzymes but fermented by the gut microflora i.e. non-starch polysaccharides, $\alpha$-galactosides. A high content of NSP in diets increases the content of less digestible carbohydrates and decreases the amount of easily digestible substances. It was found that for each $1 \%$ increase in crude fibre, the content of starch and sugars in the nitrogen free extract fraction decreased by 2.1-2.7\% (Fernández and Jørgensen, 1986). The increased intake of structural cell polysaccharides by animals is also associated with decreased ileal and faecal digestibility of protein and energy (Just, 1981; Chabeauti et al., 1991; Hauschild and Koehler, 1991; Jørgensen and Jensen, 1994, Yin et al., 1997).

In pigs the ileal digestibility of NSP of legume seeds depends on animal age and species of legume seeds, and ranges from 12 to $43 \%$ (Gdala and Buraczewska, 1997b; Gdala et al., 1997c). In the hind-gut NSP undergo microbial fermentation providing energy for the animals (Von Engelhardt et al., 1989). However, they supply pigs with less energy than starch or sucrose digested praecaecally. A large part of the digestible energy of fibrous feedstuffs is lost as methane energy (0.5-1.0\% of gross energy) and fermentation heat (Just, 1981; van Es, 1987). The relative value of energy derived from the hind-gut fermentation is about $70 \%$ of that enzymatically digested in the small intestine (Müller and Kirchgessner, 1986; Jørgensen et al., 1996). In general, the energy value of feeds depends on the relative amounts of digestible (e.g. starch, sucrose) and fermentable (e.g. NSP) substrates that it contains. In the study of Just et al. (1983) it was demonstrated that a $1 \%$ increase in dietary content of crude fibre from cellulose depressed the digestibility of gross energy by $1.3 \%$ and depressed the utilisation of metabolizable energy by $0.9 \%$ in pigs.

Resistant starch, like low digestible carbohydrates, has a lower energy value for the host than starch digested in the small intestine. In the study of Englyst and Macfarlane (1986), only $30 \%$ of resistant starch fermented by human gut bacteria was converted to volatile fatty acids. This corresponded to $25-30 \%$ of energy available from an equivalent amount of starch hydrolysed and absorbed as glucose in the small intestine. 
Legume seeds are characterised by a relatively high level of structural polysaccharides. In the total carbohydrate content of the seed, they constitute on average from 73 to $84 \%$ in different lupin species, $27 \%$ in faba beans, and $25 \%$ in peas. A three fold higher proportion of non-starch polysaccharides in the total carbohydrate content of lupin seeds in comparison with others results from the fact that lupin seeds contain only a minute amount of starch. Differences in the fat content between lupin seeds and those of pea and faba beans are also pronounced. Therefore, different portions of carbohydrates either hydrolysed by endogenous enzymes or fermented by the gut microflora and of fat result in a different energy value of the legume seeds for animals. As the effect of more intense bacterial fermentation of NSP in the hind-gut, legume seeds have a higher energy value for pigs than for poultry.

Different technological treatments are used to improve the energy value of legume seeds, among them seed dehulling. Since dehulled seeds contain less nonstarch polysaccharides, their nutritive value is higher than that of whole ones. Flis et al. (1997) reported that the crude protein content of dehulled white lupin seeds increased by $20 \%$ and that of crude fibre decreased by $67 \%$. As a consequence of changes in nutrient proportions, the nutritive value of dehulled seeds of $L$. albus and $L$. angustifolius for pigs was higher by $5-10 \%$ and $25 \%$, respectively (Fernandez and Batterham, 1995; Flis et al., 1997). A positive effect of lupin seed dehulling was also observed for chickens. The digestibility of energy increased by $18 \%$ and that of protein by $7 \%$ in chickens fed the diet containing dehulled lupin seeds (Brenes et al., 1993).

In the case of faba beans, dehulling results in the removal of a significant amount of both tannins and non-starch polysaccharides. For pigs, dehulled faba beans have a significantly higher ileal digestibility of dry matter (Buraczewska et al., 1993). In the study of Smulikowska and Chibowska (1993) dehulled faba beans had an approximately $15 \%$ higher energy value than whole seeds, and gross energy utilisation by broiler chickens increased by 10 per cent.

\section{PHYSIOLOGICAL EFFECTS OF NON-STARCH POLYSACCHARIDES}

More than $80 \%$ of the substrates fermented in the large intestine of pigs is derived from carbohydrate sources (Bach Knudsen and Jensen, 1991). Both the level and source of dietary fibre affect the total production of short chain fatty acids (SCFA) and the ratio among SCFA produced. It was demonstrated that acidification of large bowel contents, reduced transit time and increased butyrate production acted to protect humans and animals against colo-rectal cancer (Cumming and Branch, 1982). Moreover, butyrate was considered to have important implications for metabolism, structure and function of epithelial cells lining the 
large intestine (Sakata and Yajima, 1984). Bach Knudsen and Jensen (1991) reported that by including different types of dietary fibre in pig diets, total SCFA production in the large intestine increased from about $500 \mathrm{mmol} / \mathrm{d}$ on a wheat flour diet (low dietary fibre) to $2000 \mathrm{mmol} /$ day on an oat bran diet (high dietary fibre), while butyric acid production increased from $35 \mathrm{mmol} /$ day to $260 \mathrm{mmol} / \mathrm{d}$ on the same two diets. The increasing level of pea NSP in the wheat-based diet for pigs stimulates bacterial biomass production in the large intestine and increases concentration of acetate, propionate, and, particularly, butyrate acids in blood (Goodlad and Mathers, 1991). Increased butyric acid production was also observed in rats after feeding semipurified diets with increasing level of peas, fibre preparation isolated from soya bean (Goodlad and Mathers, 1990; Takahashi et al., 1992) or when galactomannans containing different galactose $(G)$ to mannose $(M)$ ratios (1G:1M, 1G:2M, 1G:4M) (Evans et al., 1992) were fed to rats. Additionally, galactomannans lowered the concentration of cholesterol in liver and blood plasma, and decreased the rate of hepatic synthesis of cholesterol. But these effects, significantly influenced by chemical composition and structure of galactomannans, were most evident when the proportion of galactose in the galactomannan was the highest.

Non-starch polysaccharides influence the endogenous nitrogen content in the digestive tract of pigs. Diets containing a high level of NSP lead to greater volumes of gastric digesta. Korczyński et al. (1997) reported that a high fibre diet (a wheat-wheat bran diet) stimulated gastric juice secretion and pepsin activity in pigs with a gastric pouch preparation, but the mechanism of fibre action on gastric secretion is not yet fully understood. The inclusion of $15 \%$ of pea hulls to the piglet diet increased the relative weight of the pancreas by $25 \%$ and the total activity of lipase, trypsin and chymotrypsin by 45,10 and $20 \%$, respectively (Freire et al., 1997). The content and type of dietary fibre is also responsible for the changes in the volume and composition of the pancreatic juice (Żebrowska, 1985). In studies of Low and Rainbird (1984) a high viscosity guar gum perfused through the jejunum of growing pigs doubled their endogenous nitrogen output. An increase, but not significant, in endogenous ileal output of most amino acids and nitrogen in pigs fed diets with increasing NDF levels was observed by Furuya and Kaji (1991). According to Grala et al. (1998) different dietary factors, including dietary fibre, influence reabsorption rather than secretion of endogenous nitrogen along the small intestine of the pigs.

A high content of dietary fibre of diets has a negative effect on nutrient digestibility in animals. The inclusion of $15 \%$ pea hulls reduced the total tract digestibility of all dietary components in piglets of different genotypes (Freire et al., 1997). Different fractions of pea seed fibre, i.e. crude fibre, neutral detergent- and acid detergent fibre, and cellulose negatively influence the digestibility of organic matter and crude protein in growing pigs too (Hauschild and Koehler, 1991). A high fibre diet decreases the apparent ileal digestibility of crude protein and amino 
acids in humans (Abrahamsson et al., 1995). An increasing level of dietary fibre in human diets also leads to increased faecal fat content. Losowsky (1978) suggested that the higher faecal output relates to an increase in unabsorbed dietary fat, an increase in the excretion of endogenous fat and fat derived from bacterial metabolism in the colon. Increased daily wet weight of faeces and defecation frequency, lowered faecal dry weight, and also reduced intestinal transit time were observed in other studies with high fibre diets (Prynne and Southgate, 1979; van Dokkun et al., 1983).

Structural cell wall polysaccharides may influence absorption of minerals from the digestive tract. Soluble fibre, as reported by Gralak et al. (1996), has only a very slight influence on mineral excretion in faeces and apparent absorption in rats. This is in agreement with previous data of Kelsay (1987), who observed no effect of pectins on $\mathrm{Ca}, \mathrm{Mg}, \mathrm{Fe}$, and $\mathrm{Zn}$ balance in human beings. However, according to Rubio et al. (1992) water-soluble NSP of faba bean may be involved in the increased loss of $\mathrm{Zn}$ and $\mathrm{Mn}$ in rats fed on faba bean diets for extended periods. ln contrast with soluble fibre, the insoluble fraction of dietary fibre from various sources significantly increased the excretion of $\mathrm{Ca}, \mathrm{Mg}, \mathrm{Fe}, \mathrm{Mn}, \mathrm{Zn}$, and $\mathrm{Cu}$ in faeces and decreased apparent absorption of minerals in rats (Gralak et al., 1996). The insoluble structural polysaccharides of faba bean hulls may interfere with the absorption of Fe from the rat gut (Rubio et al., 1992).

So far, there is limited information on the physiological effects of legume seed NSP in monogastric animals. Cockerels and ducks are able to digest only the water-soluble fraction of lupin seed NSP, while the water-insoluble fraction is practically undigested by birds (Carré et al., 1990). In a study by Eder et al. (1996) chickens fed a diet containing $35 \%$ white lupin showed lower serum concentrations of triglycerides and phospholipids, as well as total cholesterol, triglycerides and phospholipids in the high-density lipoprotein fraction. Lipids in low-density lipoproteins were not affected by the treatment.

The interest in dietary fibre in human diets relates mainly to possible health benefits arising from the effects of fibre on cancer of the colon and rectum, coronary heart disease, gallstones, plasma cholesterol, and diabetes mellitus (Trowell, 1974; Truswell, 1978; Anderson et al., 1990). Increasing the level of legume seeds in human diets at the expense of animal products such as meat would decrease the content of fat and increase the content of dietary fibre. Diets containing beans may have special advantages for diabetic patients, as bean carbohydrates may be digested and absorbed more slowly than from other foods. This is probably due to slowing of gastric emptying time (Leeds, 1982) or to impaired diffusion of glucose from the small intestine (Wolever and Jenkins, 1982). A high level of plasma lipids, especially cholesterol, may be one of the more important risk factors leading to coronary heart disease. Anderson et al. (1984) showed that dried beans (115 g/kg diet) decreased the total serum cholesterol level (on average by $19 \%$ ) and LDL 
cholesterol (on average by $23 \%$ ) in 10 hypercholesterolemic men. Serum HDL cholesterol was not significantly altered.

In general, the gastro-intestinal tract is affected by non-starch polysaccharides of the water-soluble and insoluble fractions of dietary fibre in different ways. The soluble fibre increases intestinal transit time, delays gastric emptying, and slows absorption (Low, 1985). As the result of these actions both the postprandial blood glucose concentration and serum cholesterol levels are lowered. The insoluble fraction decreases intestinal transit time, increases faecal bulk, delays glucose absorption and slows starch hydrolysis. These effects alter gastrointestinal function but do not lower serum glucose or cholesterol (Anderson et al., 1990; Topping, 1991).

From the nutritional point of view, dietary fibre is considered to be a negative factor that dilutes the energy content of diets and decreases nutrient availability for animals. However, this is not so obvious in human nutrition. Diets for children and young people should not contain high levels of dietary fibre. On the other hand, dietary fibre should be present in appreciable amounts in diets for adults as a means of preventing gastrointestinal disorders, cancer of the colon and rectum, obesity, coronary heart disease, gallstones, high plasma cholesterol levels.

\section{THE EFFECT OF SEED PROCESSING ON DIETARY FIBRE UTILISATION}

By encapsulating nutrients in intact plant cells, insoluble NSP form a physical barrier to endogenous enzymes. On the other hand, the water soluble fraction of NSP increases the viscosity of the digesta in the small intestine, depressing nutrient absorption. Thus, the use of carbohydrases of microbial origin (hemicelullase, pectinase, $\beta$-glucanase, $\alpha$-galactosidase) may enhance the nutritional value of feedstuffs containing a high level of NSP as the enzymes are presumed to disrupt cell wall polysaccharides. Investigations have established that inclusion of commercial enzyme preparations in wheat-based diets for broiler chickens significantly raised the apparent metabolizable energy of wheat from $14.26 \mathrm{MJ} \mathrm{kg}^{-1} \mathrm{DM}$ up to $15.79 \mathrm{MJ} \mathrm{kg}^{-1} \mathrm{DM}$ (Annison, 1992). The increase in the metabolizable energy was not due to complete hydrolysis of NSP by exogenous enzymes and subsequent absorption of the released sugars, but due to the significant increase in apparent pentosan digestibility ( 26 vs. $44 \%$ ) and in ileal starch digestibility ( $88 \mathrm{vs.} 98 \%$ ). A potential contribution of the main cell-wall residues released by feed enzymes to the metabolizable energy in the fowl appear to be in the order: glucose > galactose $>$ xylose $>$ arabinose $>$ galacturonic acid (Savory, 1992).

Studies on chickens showed that enzyme supplementation to legume seed diets has a positive effect on bird performance. The body weight gains of chickens and the feed to gain ratio were improved by 24 and $11 \%$, respectively, when $3 \%$ of 
Bio-Feed Pro (protease) was added to the diet containing 50\% raw L. albus seeds (Brenes et al., 1993). When Alloui et al. (1994) added 0.3\% Energex (carbohydrases) to a ration in which ground lupin seeds constituted $50 \%$, the value of metabolizable energy (AMEN) of L.luteus, L. albus, and $L$. angustifolius increased by $1.5 \mathrm{MJ} / \mathrm{kg} \mathrm{DM}$. The supplementation of the same rations with $0.3 \%$ Alpha-Gal $\left(\alpha\right.$-galactosidase) resulted in an increase of $\mathrm{AME}_{\wedge}$ only of one variety of $L$. angustifolius. Diets containing $23 \%$ of $L$. luteus or $L$. angustifolius seeds supplemented with Energex or Alpha-Gal at a level of $0.1 \%$ did not have any positive effect on the performance of birds. The enzyme preparation Energex used by the abovementioned authors in higher concentration ( $1 \%$ ) under in vitro conditions increased the degree of NDF and ADF hydrolysis in white lupin seeds by 19 and $10 \%$, respectively. Brenes et al. (1992) reported that in the presence of Bio-Feed Pro, Energex, and Novozyme ( $\alpha$-galactosidase), each included at a level of $0.1 \%$, weight gains for diets containing 15,35 and $45 \%$ lupins ( $L$. albus) significantly increased by 4,7 and $7 \%$, respectively. Enzymes also significantly improved the feed to gain ratio by 4 and $6 \%$ in diets containing 0 and $15 \%$ lupins. According to the above authors, the same enzymes added to a diet containing $59 \%$ dehulled lupins, significantly improved the weight gain $(19 \%)$, feed to gain ratio $(10 \%)$, NSP digestibility ( $9 \%$ ), and also oligosaccharide digestibility.

Enzyme supplementation of different types of diets is less effective and consistent in pigs than in poultry (Graham et al., 1986; Bedford et al., 1992). However, there are data showing that adding microbial $\beta$-glucanase, xylanase, and protease to hulless barley diets for $15-35 \mathrm{~kg}$ pigs significantly increased ileal digestibility of dry matter, gross energy, protein, and non-starch polysaccharides (Liu et al., 1997). Since enhancement in carbohydrate digestibility occurred particularly in the small intestine, less NSP reached the hind-gut and less energy was lost during bacterial fermentation. As reported by Dierick and Decuypere (1997), monoand oligomers from NSP do not stimulate volatile fatty acid (VFA) fermentation in the foregut. Significant amounts of enzymatically released hexoses can be degraded by foregut microflora to lactic acid ( $85 \%)$ and VFA (15\%). In pigs, as calculated by the authors mentioned above, the utilisation of energy from lactic acid and VFA for energy retention corresponds to about 95 and $65 \%$, respectively, of the energy absorbed as glucose from the small intestine. Pentoses are rarely attacked by the microflora of the foregut.

The supplementation of hulless barley with $\beta$-glucanase alone also resulted in significant improvement in digestibility of dry matter, crude protein and digestible energy in comparison with an unsupplemented diet (Thacker et al., 1988). Li et al. (1996) observed a linear increase in the digestibilities of dry matter, crude protein and energy when increasing levels $(0.05,0.1,0.2 \%)$ of $\beta$-glucanase were supplemented to the barley-soyabean meal diet. However, the only significant improvement in protein (by 6.9 percentage units) and energy (by 4.3 units) digestibility 
was observed when $0.2 \% \beta$-glucanase was added to the diet. In contrast to the above results, Roth-Maier and Kirchgessner (1994) did not observe any improvement in piglet performance $(7-26 \mathrm{~kg})$, when a preparation containing cellulase and xylanase activity (Roxazyme G) was added to the diet containing $15 \%$ L. albus or $30 \% \mathrm{~L}$. luteus seeds. In another study, the effect of adding different enzymes ( $\alpha$-galactosidase, xylanase, $\beta$-glucanase, $\alpha$-amylase, and protease) to cereal-based diets on the digestibility of carbohydrates, protein and fat at the terminal ileum of 8-12 week old piglets was also limited (Gdala et al., 1997). Similar results were observed for older pigs. Supplementation of diets containing $50 \%$ of whole faba bean seeds or $46 \%$ dehulled faba bean seeds with preparations containing cell wall degrading enzymes ( $0.1 \%$ Bio Feed Plus, $0.05 \%$ Energex, $0.05 \%$ Alpha Gal) and protease $(0.05 \%$ Bio Feed Pro) did not improve the digestibility of whole or dehulled faba bean seeds in pigs weighing from 38 to $70 \mathrm{~kg}$ (Gdala et al., 1995).

Various processing techniques (i.e. water and alcohol extraction, cooking, enzymes) have been applied to remove $\alpha$-galactosides from legume seeds (Saini, 1988; Nczak et al, 1992). It seems that enzymatic treatment of milled seeds is the most effective in removing these compounds (Somiari and Balogh, 1993). A microbial $\alpha$-galactosidase $(0.5 \%)$ supplemented to the diet containing $35 \%$ L. luteus or L. angustifolius significantly increased $\alpha$-galactoside hydrolysis in the small intestine of young pigs (Gdala et al., 1997b). Moreover, enzyme addition significantly increased the ileal digestibility of most amino acids.

\section{CONCLUSIONS}

Seeds of different lupin varieties contain more NSP than seeds of pea or faba bean. Lupin NSP are mainly composed of glucose and galactose, while those of pea and faba bean contain high amounts of glucose, arabinose and uronic acids.

Lupin, pea and faba bean seeds are characterised by different proportions of carbohydrates either hydrolysed by endogenous enzymes or fermented by the gut microflora, and of fat. This results in their different energy value for non-ruminants. As the effect of more intense fermentation of NSP in the hind gut, legume seeds have a higher energy value for pigs than for poultry. However, the energy value of the seeds can be improved by different treatments, i.e. seed dehulling.

Non-starch polysaccharides are found to influence both the total production of short chain fatty acids (SCFA) in pigs and the ratio among SCFA produced, to change the endogenous nitrogen content of the digestive tract of pigs and to reduce the digestibility of nutrients. Furthermore, the soluble fraction of NSP increases intestinal transit time, delays gastric emptying, and slows absorption. The insoluble fraction decreases intestinal transit time, increases faecal bulk, delays glucose absorption and slows starch hydrolysis. 
NSP are considered to be a negative factor in animal diets. But this is not so obvious in human nutrition. Diets for children and young people should contain a low level of NSP, but not for adults. For the latter NSP are considered to be a factor protecting from gastrointestinal disorders, the colon and rectum cancer, obesity, coronary hart disease, gallstones, and high levels of plasma cholesterol.

\section{REFERENCES}

Abrahamsson M., Åman P., Hallmans G, Zhang J. X., Lundin E., 1995. Excretion of amino acids residues from diets based on low-fibre wheat or high-fibre rye bread in human subjects with ileostomies. Eur. J. Clin. Nutr. 49, 589-595

Alloui O., Smulikowska S., Chibowska M., Pastuszewska B., 1994. The nutritive value of lupin seeds ( $L$. luteus, $L$. angustifolius and $L$. albus) for broiler chickens as affected by variety and enzyme supplementation. J. Anim. Feed Sci, 3, 215-227

Anderson J.W., Story L., Sieling B., Chen W. L., 1984. Hypocholesterolemic effects of oat-bran or bean intake for hypercholesterolemic men. Amer. J. Clin. Nutr. 40, 1140-1151

Anderson J.W., Deakins D. A., Floore T. L., Smith B. M., Whitis S. E., 1990. Dietary fibre and coronary hart disease. Crit. Rev. Food Sci. Nutr. 29, 95-147

Annison G., 1992. Commercial enzyme supplementation of wheat-based diets raises ileal glycanase activities and improves apparent ileal metabolisable energy, starch and pentosan digestibilities in broiler chickens. Anim. Feed Sci. Technol. 38, 105-121

Annison G. 1993., The chemistry of dietary fibre. In: S. Samman, G. Annison (Editors). Dietary fibre and beyond. Australian Prospectives. Nutritional Society of Australia, Vol.1, pp.1-18

Annison G. 1995., Feed enzymes - the sience, future development and practical aspects in feed formulation. Proceedings of the 10th European Symposium on Poulty Nutrition. Antalya (Turkey), pp. 193-201

Arora S.K., 1983. In: S. K. Arora (Editor). Chemistry and biochemistry of legumes, Edward Arnold Ltd., London, pp. 1-50

Aspinall G.O., 1970. Polysaccharides. Pergamon Press, Oxford, New York, pp. 94-102

Bach Knudsen K. E., Jensen B. B., 1991. Effect of source and level of dietary fibre on microbial fermentation in the large intestine of pigs. EAAP Publication No. 54, 389-393

Bach Knudsen K. E., 1997. Carbohydrates and lignin contents of plant materials used in animal feeding. 1997. Anim. Feed Sci. Technol. 67, 319-338

Bailey R. W., Mills S. E., Hove E. L., 1974. Composition of sweet and biter lupin seed hulls with observations on the apparent digestibility of sweet lupin seed hulls by young rats. J. Sci. Food Agric. 25, 955-961

Bedford M.R., Patience J. F., Classen H. L., Inborr J., 1992. The effect of dietary enzyme supplementation of rye- and barley-based diets on digestion and subsequent performance in wealing pigs. Can. J. Anim. Sci. 72, 97-105

Bjergegaard C., Sørensen H., Sørensen S., 1997. Dietary fibres important parts of high quality food and feeds. Proccedings of Symposium on "Dietary fibre - chemical composition and biological effects", Radzików (Poland), pp. 1-14 
Brenes A., Marquardt R. R., Guenter W., Slominski B., 1992. Broiler chick performance, gastrointestinal size, and digestibility of non-starch polysaccharides (NSP) and oligosaccharides as affected by enzyme addition to diets containing whole and dehulled lupin ( $L$. albus). Proccedings of 1st European Conference on Grain Legumes, Angers (France), pp. 477-478

Brenes A., Marquardt R. R., Guenter W., Rotter B. A., 1993 Effect of enzyme supplementation on the nutritional value of raw, autoclaved, and dehulled lupins (Lupinus albus) in chicken diets. Poultry Sci. 72, 2281-2293

Brillouet J. M., Carr, B., 1983. Composition of cell walls from cotyledons of Pisum sativum, Vicia faba and Glycine max. Phytochemistry 22, 841-847

Brillouet J.M., Riochet D., 1993. Cell wall polysaccharides and lignin in cotyledons and hulls of seeds from various lupin (Lupinus L.) species. J. Sci. Food Agric. 34, 861-868.

Buraczewska L., Gdala J., Grala W., 1992. Heal digestibility of nutrients in pigs fed diets with raw or processed field bean. Proccedings of the 1st European Conference on Grain Legume, Angers (France), pp. 517-518

Buraczewska L., Gdala J., Grala W., 1993. The effect of dehulling and steaming of faba beans on nutrients ileal digestibility in growing pigs (in Polish). Biul. Nauk., ART Olsztyn, 12, 103-107

Carré B., Brillouet J. M., Thibault J. P., 1985. Characterization of polysaccharides from white lupin (Lupinus albus L.) cotyledons. J. Agric. Food Chem. 33, 285-292

Carré B., Derouet L., Leclerq B., 1990. The digestibility of cell-wall polysaccharides from wheat (bran or whole grain), soybean meal, and white lupin meal in cockerels, muscovy ducks, and rats. Poultry Sci. 69, 623-633

Cerning J., Saposnik A., Guilbot A., 1975. Carbohydrate composition of horse beans (Vicia faba) of different origin. Cereal Chem. 52, 125-138

Cerning-Beroard J., Filiatre A., 1976. A comparison of the carbohydrates composition of legume seeds: horsebeans, peas, and lupines. Cereal Chem. 53, 968-978

Chabeauti E., Noblet J., Carré B., 1991. Digestion of plant cell walls from four different sources in growing pigs. Anim. Feed Sci. Technol. 32, 207-213

Colonna P., Mercier C., 1979. Les amidons de légumineuses: aspects, composition, structure et properiétés physico-chimiques. Lebensm. Wiss. Technol. 12, 1-12

Cummings J.H., Branch W.L., 1982. Postulated mechanisms whereby fibre may protect against large bowel cancer. In: G.V. Vahouny, D.Kirtchevsky (Editors). Dietary fibre in health and disease London: Plenum Press, pp. 313-325

Cummings J.H., Englyst H. N., Wiggins H. S., 1986. The role of carbohydrates in lower gut function. In: The nutritional reemergence of starchy foods. Naeringsforsk (Suppl.) 30, 17-21

Cummings J.H., Beatty E. R., Kingman S. M., Bingham S. A., Englyst H. N., 1996. Digestion and physiological properties of resistant starch in the human large bowel. Brit. J. Nutr. 75, 733-747

Daveby Y.D, Åman P., 1993. Chemical composition of certain dehulled legume seeds and their hulls with special reference to carbohydrates. Swedish J. Agric. Res. 23, 133-139

Dierick N., Decuypere J., 1997. Microbial degradation of enzymic released non-starch polysaccharide constituents in the small intestine of pigs. EAAP Publication No. 88, 421-425

Eder K., Roth-Maier D., Kirchgessner M., 1996. The effect of enzyme supplements and high amounts of white lupins on concentrations of lipids in serum and meat in fattening chickens. Arch. Anim. Nutr. 49, 221-228

Englyst H. N., Macfarlane G. T., 1986. Breakdown of resistant and readily digestible starch by human gut bacteria. J. Sci. Food Agric. 37, 699-706

Englyst H., Kingman S. M., Hudson G. J., Cummings J. H., 1996. Measurment of resistant starch in vitro and in vivo. Brit. J. Nutr. $75,749-755$. 
Evans A.J., Hood R. L., Dakenfull D. G., Sidhu G. S., 1992. Relationship between structure and function of dietary fibre: a comparative study of the effect of three galactomannans on cholesterol metabolism in the rat. Brit. J. Nutr. 68, 217-229

Evans A.J., Cheung P. C. K., Cheetham N. W. H., 1993. The carbohydrate composition of cotyledons and hulls of cultivars of Lupinum anglstifolius from western Australia. J. Sci. Food Agric. $61,189-194$

Fernández J. A., Jørgensen J. N., 1986. Digestibility and absorption of nutrients as affected by fibre content in the diet of the pig. Quantitative aspects. Livest. Prod. Sci. 15, 53-71

Fernandez J. A., Batterham E. S., 1995. The nutritive value of lupin-seed and dehulled lupin-seed meals as protein source for growing pigs as evaluated by different techiques. Anim. Feed Sci. Technol. 53, 279-296

Flis M., Sobotka W., Meller Z., 1996. The use of dehulled or fat supplemented yellow lupin seeds in feeding growing pigs. J. Anim. Feed Sci. 5, 49-62

Flis M., Sobotka W., Zduńczyk Z., 1997. Effect of variety and dehuiling on nutritional value of white lupin seeds in feeding growing pigs. J. Anim. Feed Sci. 6, 521-532

Freire J. P. B., Peiniau J., Cunha L. F., Almeida J. A. A, Aumaitre A.. 1997. Comparitive effect of pea hulls anf fat source on the digestive performance and the activity of pancreatic and intestinal enzymes in the Large White and Alentejano weaned piglets. EAAP Publication No. 88, 554-557

Furuya S., Kaji Y., 1991. The effects of feed intake and dietary fibre levels on the endogenous ileal amino acid output in growing pigs. EAAP Publication No. 54, 190-195

Gdala J., Buraczewska L.. Grala W., 1992. The chemical composition of different types and varietes of pea and the digestion of their protein in pigs. J. Anim. Feed Sci. 1, 71-78

Gdala J., Buraczewska L., Wasilewko J., Grala W., 1995. Ileal digestibility of nutrients in pigs fed diets with whole or dehulled faba beans (Vicia faba L.) supplemented with enzymes. Proccedings of the 2nd European Conference on Grain Legumes, Copenhagen (Denmark), pp. 264-265

Gdala J., Buraczewska L., 1996. Chemical composition and carbohydrate contents of seeds of several lupin species. J. Anim. Feed Sci. 5, 403-416

Gdala J., Buraczewska L., 1997a. Chemical composition and carbohydrate content of seeds of several varieties of faba bean and pea. J. Anim. Feed Sci.6, 123-135

Gdala J., Buraczewska L., 1997b. Ileal digestibility of pea and faba bean carbohydrates in growing pigs. J. Anim. Feed Sci. 6, 235-245

Gdala J., Jansman A. J. M., Buraczewska L., Huisman J., van Leeuwe P., 1997c. The influence of $\alpha$-galactosidase supplementation on the ileal digestibility of lupin seed carbohydrates and dietary protein in young pigs. Anim. Feed Sci. Technol. 67, 115-125

Gdala J., Johanson H. N., Bach Knudsen K. E., Knap I. H., Wagner P., Jørgensen O. B., 1997d. The digestibility of carbohydrates, protein and fat in the small and large intestine of piglets fed nonsupplemented and enzyme supplemented diets. Anim. Feed Sci. Technol. 65, 15-33

Goodlad J. S., Mathers J. C., 1990. Large bowel fermentation in rats given diets containing raw peas (Pisum sativum). Brit. J. Nutr. 64, 569-587

Goodlad J. S., Mathers J. C., 1991. Digestion by pigs non-starch polysaccharides in wheat and raw peas (Pisum sativum) fed in mix diets. Brit. J. Nutr. 65, 259-270

Graham H., Hesselman K., Jonsson E., Åman P., 1986. Influence of $\beta$-glucanase supplementation on digestion of a barley-based diet in the pig gastrointestinal tract. Nutr. Rep. Int. 34, 1089-1096

Graham H., Åman P., Petterson D., 1990. Chemical analysis and nutritional aspects of dietary fibre. Comp. Physiol. 5, 242-253

Grala W., Buraczewska L., Wasilewko J., Verstegen M. W. A., Tamminga S., Jansman A. J. M., Huisman J., Korczyński W., 1998. Flow of endogenous and exogenous nitrogen in different 
segments of the small intestine in pigs fed diets with soyabean concentrate, soyabean meal and rapeseed cake. J. Anim. Feed Sci. 7, 1-20

Gralak M.A., Leontowicz M., Morawiec M., Bartnikowska E., Kulasek G.W., 1996. Comparison of the influence of dietry fibre sources with different proportions of soluble and insoluble fibre on $\mathrm{Ca}, \mathrm{Mg}, \mathrm{Fe}, \mathrm{Zn}, \mathrm{Mn}$ and $\mathrm{Cu}$ apparent digestion in rats. Arch. Anim. Nutr. 49, 293-299

Hansen I., 1989. Dietary fibre; chemical and physical characteristics and effects on digestibility of nutrients and energy metabolism in rats. PhD. Thesis. Department of Animal Physiology and Biochemistry, The Royal Veterinary and Agricultural University, Copenhagen, pp. 71-83

Hauschild A., Koehler R., 1991. Influence of dietary fibre on digestibility of protein and organic matter of different pea genotypes in growing pigs. Proceedings of 6 th International Symposium on Protein Metabolism and Nutrition, Herning (Denmark), pp. 21-23

Henry R. J., 1985. A comparison of the non-starch polysaccharides in cereal grains. J. Sci. Food. Agric. 36, 1234-1253

Just A., 1981. Energy evaluation of feedstuffs and diets for growing pigs. Pigs News Inf. 2, 401-405

Just A., Fernández J.A., Jørgensen H., 1983. The net energy value of diets for growth in pigs in relation to the fermentative processes in the digestive tract and the site of absorption of the nutrients. Livest. Prod. Sci, 10, 171-186.

Jørgensen H., Jensen B. B., 1994. The effect of dietry fiber on digestibility, microbial activity, and microbial gas production in various regions of the gastrointestinal tract of pigs. EAAP Publication No. 80, 273-276

Jørgensen H., Zhao X. Q., Eggum B. O., 1996. The influence of dietary fibre and enviromental temperature on the development of the gastrointestinal tract, digestibility, degree of fermentation in the hind gut and metabolism in pigs. Brit. J. Nutr. $75,365-378$

Kass M. L., Van Soest P. J., Pond W. G., 1980. Utilization of dietary fibre from alfalfa by growing swine. Il. Volitale fatty acid concentrations in and disappearance from gastrointestinal tract. J. Anim. Sci. 50, 192-197

Kelsay J. L., 1987. Effects of fiber, phytic acid, and oxalic acid in the diet on mineral bioavailability. Amer. J. Gastroen. 82, 983-986

Kieliszewski M., Lamport D. T., 1987. Purification and partial characterization of hyroxyproline rich glycoprotein in a graminaceous monocot, Zea mays. Plant Physiol. 85, 823-827.

Korczyński W., Budzyńska M., Żebrowska T., 1997. The influence of dietary fibre on gastric secretion in pigs. EAAP Publication No. 88, 613-616

Krauze D. O., Easter R. A., Mackie R. L., 1994. Fermentation of stachyose and raffinose by hind-gut bacteria of the weanling pig. Lett. Appl. Microbiol. 18, 439-352

Losowsky M. S., 1978. Effects of dietary fibre on intestinal absorption. J. Plant Foods 3, 129-139

Low A. G., A. Rainbird L., 1984. Effect of guar gum on nitrogen secretion into isolated loops of jejunum in growing pigs. Brit. J. Nutr. 52,499-505 Low A.G. 1985. Role of dietary fibre in pigs diets. In: H. Haresign, D.J.A. Cole (Editors). Recent advances in animal nutrition. Butterworhs, pp. 87-112

Low A. G., 1985. Role of dietary fibre in pigs diets. In: W. Haresign, D.J.A. Cole (Editos). Recent advences in animal nutrition, Butterwoths, pp. 87-112

Li S., Sauer W. C., Mosenthin R., Kerr B., 1996. Effect of $\beta$-glucanase supplementation of cereal based diets for starter pigs on the apparent digestibilities of dry matter, crude protein and energy. Anim. Feed Sci. Technol. 59, 223-231

Liu Y. G., Baidoo S. K., Schulze H., 1997. Digestive responses of young pigs on microbial enzymes added to hulless barley diets: energy and amino acid digestibility. EAAP Publication No. 88 , $462-465$ 
Mahomed A. A., Rayas-Duarte P., 1995. Nonstarch polysaccharides analysis of cotyledon and hulls of Lupinus albus. Cereal Chem. 72, 648-651

Mangan J. L., 1988. Nutritional effects of tannins in animal feeds. Nutr. Res. Rev. 1, 209-231

Ménez M. H .M., Derivi S. C. N., Fernandes M. L., Oliveira A. M. G., 1993. Insoluble dietary fiber of grain food legumes and protein digestibility. Arch. Latinoamer. Nutr, 43, 66-72

Müller H. L., Kirchgessner M., 1986. Some aspects of energy utilization in pigs. Pigs News Inf. 7, 419-424

Naczk M., Myhara R. M., Shahidi F., 1992. Effects of processing on the oligosaccharides of oilseed and legume protein meals. Food Chem. 45, 193-197

Narasinga Rao B. S., Prabhavathi T., 1982. Tannin content in foods commonly consumed in India and its influence on ionisable iron. J. Sci. Food Agric. 33, 89-96

O'Neill M. A., Selvendran R. R., 1980. Glycoproteins from the cell wall of Phaseolus coccineus. Biochem. J. 187, 53-63.

Petterson D. S., Mackintosh J. B., 1994. The chemical composition of lupin seed grown in Australia. Proceedings of Australian Lupin Technical Symposium, Perth, pp. 39-48

Prynne C. J., Southgate D. A. T., 1979. The effects of a supplement of dietary fibre on faecal excretion by human subjects. Brit. J. Nutr. 41, 495-503

Ralet M - C., Thibault J - F., 1992. Composition, structure, and physico-chemical properties of commercial pea hull fibres. Proceedings of the 1st European Conference on Grain Legumes Angers (France), 407-408

Roth-Maier D. A., Kirchgessner M., 1994. Zum Einsatz weisser und gelber Lupinen (Lupinus albus und Lupinus luteus L.) in kombination mit Enzymzulagen in der Ferkelaufzucht. Agribiol. Res. 47, 312-317

Rubio L.A., Grant G., Bardocz S., Dewey P., 1992. Mineral excretion of rats fed on diets containing faba beans (Vicia faba L.) or faba bean fractions. Brit. J. Nutr. 67, 295-302

Rybka M., 1993. Cell wall polysaccharides of mono- and dicotyledon plants (in Polish). Post. Nauk rol. $40,89-100$

Saini H., 1988. Extractability and evaluation of $\alpha$-galactosides of sucrose in leguminous seeds. Food Chem. 28, 149-157

Saini H., 1993.Distribution of tannins, vicine and covicine activity in legume seeds. EAAP Publication No. 70, 95-100

Sakata T., Yajima T., 1994. Influence of short chain fatty acids on the epithelial cell division of digestive tract. Quart. J. Exp. Physiol. 69, 639-648

Savory C. J., 1992. Metabolic fates of U-14C-labelled monosaccharides and an enzyme-treated cellwall substarate in the fowl. Brit. J. Nutr. 67, 103-114

Somiari R. I., Balogh E., 1993. Effect of soaking, cooking and crude a-galactosidase treatment on the oligosaccharide content of cowpea flours. J. Sci. Food Agric. 61, 339-343

Smulikowska S., Chibowska M., 1993. The effect of variety, supplementation with tryptophan, dehulling and autoclaving on utilozation of field bean (Vicia faba L.) seeds by broiler chickens. J. Anim. Feed Sci. 2, 181-188.

Southgate D. A. T., 1982. In: G.V. Vahouny, P. Kritchevsky (Editors). Dietary fibre in health and disease. Plenum Press, New York, pp. 1-7

Tallbot L. D., Ray P. M., 1992. Molecular size and separability features of pea cell wall polysaccharides. Plant Physiol. 98, 357-368

Takahashi I., Egashira Y., Sanada H., Ayano Y., Maeda H., Terashima M., 1992. Effects of soyabean dietary fibre on grow rate, digestibility and gastrointestinal transit time in rats. J. Jpn. Soc. Nutr. Food Sci. 45, 277-284 
Taverner M R., Drago M., Rayner C. J., 1983. A comparison of the extent and site of energy and protein digestion of wheat, lupin and meat and bone meal by pigs. J. Sci. Food. Agric. 34, $122-128$

Thacker P. A., Campbell G. L., GrootWassink J. W. D., 1988. The effect of $\beta$-glucanase supplementation on the performance of pigs fed hulless barley. Nutr. Rep. Int. 38, 91-99

Topping D. L., 1991. Soluble fiber polysaccharides: effects on plasma cholesterol and colonic fermentation. Nutr. Rev. 49, 195-203

Trowell H., 1974. Dietary fibre, coronary heart disease and diabetes mellitus. Part 2. Coronary heart disease and diabetes mellitus. Plant Food for Man 1, 91-97

Truswell A. S., 1978. Effect of different types of dietary fibre on plasma lipids. J. Plant Foods 3, $105-112$

Van Dokkun W., Pikaar N. A., Thissen J. T. N. M., 1983. Physiological effects of fibre-rich types of bread. 2. Dietary fibre from bread: digestibility by the intestinal microflora and water-holding capacity in the colon of human subjects. Brit. J. Nutr. 50, 61-74

Van Es A. J. H., 1987. Energy utilization of low digestibility carbohydrates. In: D.C. Leegwater, V.J. Feron, R.J.J. Hermus (Editors). Low digestibility carbohydrates. Pudoc Wageningen, pp. $121-127$

Von Engelhardt W., Roennau K., Rechkemmer K, Sakata T., 1989. Absorption of short-chain fatty acids and their role in the hingut of monogastric animals. Anim. Feed Sci. Technol, 23, 43-53

Weightman R. M., Mathers J. C., Wilcockson S. J., 1993. Concentration and composition of nonstarch polysaccharides in three pea varieties of contrasting seed type: effects of maturation and growing conditions. Plant Varieties and Seeds 6, 139-142

Weightman R. M., Renard C. M. G. C., Tibault J. P., 1994. Structure and properties of the polysaccharides from pea hulls. I. Chemical extraction and fractionation of the polysaccharides. Carbohyd. Polym. 24, 139-148

Wolever T. M. S., Jenkins D. J. A., 1982. The glycaemic index; implications of dietary fibre and the digestibility of different carbohydrate foods in the management of diabetes. J. Plant Foods 4 , $127-138$

Żebrowska T., 1985., The influence of the level and source of fibre in the diet on the exocrine pancreatic secretion in growing pigs. Proceedings of the 3 rd International Seminar on Digestive Physiology in the Pig, Copenhagen (Denmark), pp. 152-154

Yin Y-L., McEvoy J., Schulze H., McCracken K. J., 1997. Effects of levels of dietary non-starch polysaccharides (NSP) and feed enzymes on digestibility and ileal concentration of volatile fatty acids (VFA) in growing pigs. EAAP Publication No. 80, 502-505

\section{STRESZCZENIE}

\section{Skład, cechy i wartość pokarmowa wlókna pokarmowego nasion roślin strączkowych}

Nasiona bobiku, grochu i łubinu zawierają znaczne ilosci polisacharydów nieskrobiowych (NSP). Średnia zawartość NSP w kilogramie suchej masy nasion bobiku wynosi $177 \mathrm{~g}$, grochu $186 \mathrm{~g}$, a w nasionach łubinu, w zależności od gatunku, jest ich od 320 do 400 g. Nasiona łubinu wąskolistnego (Lupinus angustifolius) zawierają więcej NSP niż nasiona łubinu żółtego (Lupinus luteus) czy białego (Lupinus albus). Różnice te wynikają z różnej zawartości składników polisacharydów nieskrobiowych, głównie ramnozy, ksylozy, galaktozy i kwasów uronowych. Glukoza i galaktoza to 
główne składniki NSP nasion łubinu, natomiast glukoza, arabinoza i kwasy uronowe dominują w NSP nasion grochu i bobiku.

Ilość węglowodanów rozkładanych przez ezymy trawienne w przewodzie pokarmowym zwierząt i tych, które są fermentowane w jelicie grubym, a także zróżnicowana zawartość thuszczu powodują, że nasiona bobiku, grochu i lubinu mają różną wartość energetyczną dla zwierząt monogastrycznych. Jest ona wyższa dla świń niż dla drobiu, co wiąże się z intensywniejszą fermentacją bakteryjną polischarydów nieskrobiowych w jelicie grubym świń.

Wysoki udział NSP w dawkach dla zwierząt obniża strawność składników pokarmowych i ich wchłanianie w przewodzie pokarmowym, natomiast w żywieniu ludzi może on wykazywać pozytywne działanie.

Nasiona roślin strączkowych poddawane są zabiegom technologicznym, np. odłuszczanie, dodatek enzymów mikrobiologicznych, mającym na celu zwiekszenie wartości pokarmowej tych nasion dla zwierząt monogastrycznych. 